\title{
Demystifying the Relationship between Decentralization and Villagers' Welfare
}

\author{
Khairu Roojiqien Sobandi, Political Science Department, Faculty of Social and Politics of Jenderal Soedirman \\ University, E-mail: khairu.sobandi@gmail.com*) \\ Solahuddin Kusumanegara, Political Science Department, Faculty of Social and Politics of Jenderal Soedirman \\ University, E-mail: solahuddin.kusumanegara@ yahoo.com
}

\begin{abstract}
Theoretically, political decentralization aims at creating prosperity for society, however it was not the case in Indonesia because the creation of autonomous regions with its authorities are unable to strengthen grassroots people, to understand and coping their problems through bottom-up planning. It is no wonder, decentralization failed to contribute in creating prosperity. This research analyses the Villages' Middle Term Planning (RPJMDes) with qualitative methods. The result shows that strengthening villagers failed substantively to acknowledge villagers' involvement in planning RPJMDes. Furthermore, the process is glaringly misguided because RPJMDes heavily focusing on physical development without taking into account economic potential. The next failure indication is that RPJMDes was unable to disclosed local economic rent seeking, which is the main problem for farmers in marketing their products. In short, the root of the problem is because of supra village structure focusing on short term economical interests and the existence of villagers' paternalistic culture.
\end{abstract}

Keywords: decentralization, bottom-up planning, villagers' welfare

\section{Introduction}

In axiology, political decentralization practices are part of democracy manifestation. It is shown by the contemporary situation where political decentralization is underlying the practices of majority government in the world. For about 95 percent, countries in the world are changing their system from centralization to decentralization (World Development Report /World Bank Report 2001/2002). Decentralization viewed as a system that more responsive to the diversity of public aspiration and the governmental structure in grassroots level and its local wisdom. However, the problem is the ability of the local government in strengthening and holds important roles in creating public welfare to the grassroots level.

The Indonesian experiences after reform period in practicing decentralization are showing small development portion specifically for grassroots people. At the moment, village's position is still in the peripheral area and structurally subordinated by doing medebewind duties from the local government and even the central government. The relationship between village and supra village is a zero-sum relationships. Various evaluation have been done by governmental and non-governmental institutions which stated that there is no correlation between decentralization and the improvement of public prosperity especially for the lowest level of society (Local Autonomy Division of Internal Affairs Department [DitjenOtonomi Daerah DepartementDalamNegeri], 2002; Eko (ed), 2008,Ratnawati, 2006; Kusumanegara, 2011). The replacement of Regulation No.22/1999 by No. $32 / 2004$ of Local Government and specifically, the creation of the Regulation No. 6/2014 of Village are the result of the evaluations for boosting the linkage between decentralization and the prosperity by giving greater responsibility to local government in strengthening the villages.

Historically, village is admitted as a self governing community that open up public spaces to create agenda and formulate policies based on their own initiative (Kartohadikoesoemo, 1984). Here, public policy and planning aspect that is created 
autonomously are utmost crucial. Furthermore, based on its status, the implementation of political decentralization in Indonesia should be based on participative bottom-up policy and planning (Eko-ed, 2005). Therefore, the people are able to dig out more strategic issues surround themselves with advance solutions collectively and at the same time, bottomup planning can be used as a starting point in strengthening the village by coping the village's interests rather than the supra village's interests.

\section{2. $\quad$ Research Method}

This research applied a case study approach to present a holistic form in analyzing a phenomenon of RPJMDes and more sensitive information capture qualitative descriptive, with relatively still maintaining the integrity of the object, meaning that the data collected as a case study was studied as an integrated whole. Data collections used observation, in-dept interview, documentation, and Focus Group Discussion with interactive model as data analysis(Strauss, A., \& Corbin, J.,1990).

\section{Discussions}

\subsection{Minimax Principal in Villages Strategic}

\section{Planning in Purbalingga}

The development of Village on Regulation No.32/2004, Ministry of Internal Affairs' rules(Permendagri) No. 37/2007, and Ministry of Internal Affairs' rules No. 66/2007 stated that implementation of village development should be based on strategic planning that created by villagerscollectively and implemented for the next five years. The result of strategic planning design is a document of Villages' Middle Term Planning (well known as RPJMDes) derived from the vision and mission of elected village leader and legitimized with village legislative body (well known as BadanPermusyawaratanDesa, BPD) through policy (known as Village Regulation or PeraturanDesa). In coping village development, RPJMDes act as the heading of the annual village planning.

Nevertheless, after more than ten years (2000 to 2010), surprisingly all villages in Purbalingga Regency, Central Java never designs the RPJMDes. This crucial issue imply that village development run as same as in the New Order Era where villagers merely do what the supra village told to do. Here, development program after reform period is not focusing on how to strengthen and improve villagers' welfare. Furthermore, the program is simply accommodating oligarchic interests of bureaucrats, politician and local entrepreneurs. They are the rent seekerswho are the main problem forvillagers' economic activities specifically, agricultural and traditional industries.

After 2010, villages in Purbalinggabegan to design the RPJMDes (2010-2014). The design of the 20102014RPJMDes was triggered by the obligation for villagers when they received the fund of National Society Empowerment Program (known as Program NasionalPemberdayaanMasyarakat, PNPM) through Purbalingga local government. The RPJMDes design process seems as a reactive action and give no room for villagers' participation and at the same time, the design process only facilitate the local elites notably the head of the village and other local elites directly set up village forum without accommodating the voices of the villagers through the lowest dialogue forum (Dusun). Here, the head of the village shortly asked the villages' elites to short the RPJMDes program draft into an annual village program. In this limited elitist forum, there is no strategic issue that is being discuses which actually this strategicissue is the foundation of the RPJMDesexistence. Moreover, the aggregation and finishing the RPJMDes 
document completely is in the hand of the village government and leave no place for disseminating the document to the villagers. As a result, there is huge gap between strategic issues with the existing program and the worst situation is that RPJMDesbetween a village to other village is about the same or we called it a "copy and paste" document.

Responding these circumstances, the local government does nothing because of rationalpragmatic considerations among local government officials by assuming that the PNPM program, for the villagers, is a value added for village development. In the perspective of game theory, the government has practicing the minimax principal (Kusumanegara, 2010) by receiving the PNPM program which considered giving more benefits directly by sacrificing the RPJMDEs formulation that has no direct economical advantages. The Minimax model did not explain on how the actors make their decisions precisely, however this model does explain on how the actors formulate rational policy in a competitive situation. The key concept of game theory is the strategy. Strategy is a rational decision making where a set of activities designed to gain optimum payoff after an actor or actors forecast the other actors do or not to do.

In the case of RPJMDes, the local government faces two options that is a perfect formulation of RPJMDes which time consuming and longer processes with no guarantee of government and villagers' capacity in formulating the RPJMDes or the governmentwould do a pragmatic and rapid action in acquiring the PNPM fund so that the villagers immediately gain direct benefits. At the same time, the central government reluctantly concern toward the RPJMDes for every village in Indonesia. The decision in receiving the PNPM program by sacrificing RPJMDes quality is seen as a rational action of local government so that the fund flowing out from the central government for the villages' development through Village meeting forum (known as MusyawarahDesa, Musdes). The local government thought that the central government put more concern on PNPM program rather than RPJMDes quality because there is no regulation or what so ever in regency/local level about how to integrate the RPJMDes formulation with the others planning, includes PNPM program, in village level.

Consequently, the RPJMDes formulation process full with political nuance and it seems like a arbitrary, negotiation, and interests consensus forum between the bureaucrats, politician, and local entrepreneur that notably known as local elites itself. It is not surprising the main priority program of RPJMDes is a physical program without productive economic strengthening and at the time, RPJMDes program can be utilized as mechanism of conflict preventionbetween village's elites in implementing village development program. In other words, RPJMDes formulation process gives direct impact on the sustaining of status quo position of the rent seekers in village level. As a result, rarely conflicts arise between elites in villages in Purbalingga.

The lack of villagers' involvement in RPJMDes formulation process is admitted by villagers because they considers the foundation of RPJMDes formulation or even other planning program is the village government officials' and local elites' matter and also it has nothing to do with villagers' economical interests. All this time, villagers' economic activities have no relations with the village government officials' concern. These situationsat least explain on why villagers have little room for 
their participation in village development. Moreover, villagers participation exist and arise if only the villagers thought that there are benefits that they may gain and if villagers gain opportunities to contribute in formulating the programs (Lubkemann, 2001).

This condition at the moment is not beneficial for villagers economically. However, there is a hope, based on the latest development, in Panusupan village, as one of the site of this research, by the existence of villagers' creative economic activities for solving villagers' economical problem by creating small scale cow cattle in cooperating with Islamic CSOs like the youth from Muhammadiyah and Ansororganizations and supported by local entrepreneurs in Purbalingga. This cooperation gives more benefits for villagers compared to the cooperation with village's bureaucrats, politician and entrepreneurs.

\subsection{From Agent of Change to Rent Seekers}

In political economy perspective, a strategic and fundamental issue in achieving excellence self-reliant economic development performance is the existence of independent and competitive capitalist class. However, this type of capitalist class rarely found in Indonesia. A study of Robinson (1986) in Indonesia and Kunio (1988) in Southeast Asia acknowledge that capitalist class in national level arise through its historical experiences of the creation of the rent capitalist that drive the existence of civilian bureaucrats and military rent seekers. Most developing entrepreneurs are the one that closely related to government such as family or colleague of high level government officials. Their successes in business depend on their privilege, protection and reward to bureucrats. The government officials act as capitalist a bureaucrat that is the government officials' retirement or the high level on duty officials who is exploiting their position in accumulating capital. Up to the end of the New Order era, the relationship between politico businessesfull with rent nuance also exist in local level and even more in village level.

The implementation of political decentralization in village level, which centered strategic planning and villagers' participation aspect, are failed to acknowledge rent capitalist practices and rent seekers as a strategic issue that burden villagers' productivities. As a result, the development in grassroots level can be a miniature model to see politico business indications in national level with different history as what happen in villages in Purbalingga.

Historically, the existence of rent capitalist and rent seekers begin with villagers' education background as found in two sites of research, educated human resources scarcities in village level caused the one who have higher educational background have bigger opportunities for taking the head of the village position. In Panusupan village, for example, modernizations in 1980s -2010 led by a Junior High School graduation as head of village. They, the one whoact as development agents, involved in all social activities in socializing the development program designed by the government. These actors also formulate policies and programs in village level to guarantee modernization program success. They also often involved in solvingvarious dispute between villagers. The villagers' necessities have put these "agent" not only as village bureaucrats but also as notable figures (local elites). In day to day life, they become patron and being obeyed by the villagers. In other words, these considerable high educational people hold strategic position and dominate the decision making and furthermore the villagers' 
socioeconomic relationship. In the context of the relationships between state and society, these agentsare act as inter-mediator between state and society.

In economic activities, the exploitation of village potential in form of agricultural business development and traditional industry by central and local government is without open the access for villagers in marketing their own products. Consequently, marketing aspect, for villagers, become the main burden for village top products. This circumstances reveals that the burden of the farmers, like what happen in New Order era when farmers have no access and controls toward market input and output (Mas`oed, 1994). As a result, farmers are controlled by entrepreneurs from outside their neighborhood. Bureaucrats, politicians, and local elites are the actor who able to gain market access. As entrepreneurs, by cooperating with other business person outside the village and in regency level, they also take advantages from villagers' economic activities by setting up the price for villagers. The domino effect is the villagers' stagnant business income. An extreme example of this rent practices is the fall of snake fruits up to only 2,500 Rupiah (0.4 US Dollars) per kilograms in 2000s. At the same time, the production cost reached 5,000 Rupiah per kilograms. Similar rent practices to traditional industry product; such as handmade mattress that consume more than a week for a mattress, the farmers only being paid for Rp.10,000 (0.9 US Dollars) per mattress.

The effort the getting away from rent seekers networks by villagers is by creating agricultural commodity diversifications, but the lack of the access from the villagers of marketing caused no significant result of agricultural products in improving farmers' income. Villagers also equipped themselves by entering farmers' group organizations. For example, in Panusupan there are 9 active farmers and fisherman's groups with routine meeting to develop their members' productivities. However, the strength of the rent seekers figure in the groups' organizers makes them gain personal benefits. Similar to the farmers' group, the breaking up of cooperation organizations in village is also profiling the rent seekers as the top problem by trapping farmers through high debt interest.

\section{Conclusions}

Decentralization practices in grassroots level is facing huge challenges, in the case of RPJMDes (bottom-up planning), it is the structure of supra village that more concern on short term economical interests and at the same time, it is worsen by villagers' paternalistic culture.

\section{References}

1) DitjenOtda Depdagri.(2002). Kerangka Dasar Model Monitoring dan Evaluasi Otonomi Daerah. Jakarta: Subdit Evaluasi Direktorat Fasilitasi Kebijakan dan Pelaporan Otonomi Daerah Ditjen Otda

2) Eko, Sutoro (ed). (2005). Prakarsa Desentralisasi dan Otonomi Desa. Yogyakarta: IRE Press

3) Eko, Sutoro, (2008). Masa Lalu, Masa Kini, dan Masa Depan Otonomi Desa. Yogyakarta: IRE

4) Kartohadikoesoemo, Soetardjo. (1984). Desa. Jakarta: BalaiPustaka,.

5) Kunio, Yoshihara.(1988). The Rise of Ersatz Capitalism in Southeast Asia. Singapore: Oxford University Press 
6) Kusumanegara, Solahuddin,(2010). Model danAktor Dalam Proses Kebijakan Publik. Yogyakarta: Gavamedia

7) Kusumanegara, Solahuddin (ed.). Dinamika Politikdan Pembangunan Pedesaan dalam Demokratisasi. Purwokerto: Unsoed Press, 2011.

8) Lubkemann, Stephen C.(2001). Rebuilding Local Capacities in Mozambique: The National Health System and Civil Society. In Smillie, Ian (ed),Patronage or Partnership: Local Capacity Building in Humanitarian Crises. USA: Kumarian Press.

9) Mas`oed, Mohtar.(1994). Birokrasi, Politik dan Pembangunan.Yogyakarta: PustakaPelajar,.

10)Ratnawati, Tri. (2006). Potret Pemerintahan Lokal di Indonesia di Masa Perubahan:Otonomi Daerah Tahun 2000 - 2005. Yogyakarta: Pustaka Pelajar.

11)Robison, Richard.(1986). Indonesia: The Rise of Capital. Sydney: Allen and Unwin Pty, Ltd

12)Strauss, A., \& Corbin, J. (1990). Basics of Qualitative Research: Grounded Theory Procedures and Techniques. Newbury Park, CA: Sage.

13) The World Bank.(2002). World Development Report 2001-2002. Washington D.C. USA. 